\title{
THE PRESERVATION OF MILK WITH THE ADDITION OF ANTIBACTERIAL AND AROMATIC SUPPLEMENTS PRODUCED IN INDONESIA
}

\author{
TATIK KHUSNIATI ${ }^{1 *}$ AND YANTYATI WIDYASTUTI ${ }^{2}$ \\ ${ }^{1}$ Microbiology Division, Research Center for Biology, Indonesian Institute of Sciences \\ Jl. Raya Bogor-Jakarta Km 46 Cibinong 16911. INDONESLA \\ ${ }^{2}$ Research Center for Biotechnology, Indonesian Institute of Sciences
}

\begin{abstract}
The preservation of milk with additional antibacterial and aromatic supplements, produced in Indonesia, was investigated. Organoleptic performances of milk with the addition of 10\% supplements, made as juices, were tested by panellists, and the total bacteria, protease activities, lipase activities and acidities, were detected by total plate counts, azocasein method, modified dole extraction and base-acid titration, respectively. Out of the 27 supplemented skim and whole milk samples, 15 whole milk samples and 10 skim milk samples were selected as acceptable, based on their better organoleptic performances, their lower bacterial counts, protease and lipase activities, and their acidities percentages which were not significantly different, compared to that of control, at 5 days after the expiry date $(\mathrm{P}<0.05)$. These 15 whole milk samples contained honey, cinnamon, citronella, ginger, turmeric, galingale, wild ginger, nutmeg, pepper, clove, galangale, green tea, bamboo leaf, garlic leaf and aloe vera; and the 10 skim milk samples contained honey, cinnamon, citronella, ginger, galingale, pepper, galangale, green tea, bamboo leaf and aloe vera.
\end{abstract}

Key words: milk, preservation, antibacterial and aromatic supplements, protease, lipase

\section{INTRODUCTION}

Pasteurised milk spoils at refrigerated temperatures due to the activities of psychotropic bacteria, Pseudomonas spp., and the main species is Pseudomonas fluorescens (Deeth et al. 2002; Chandler et al. 1990; Craven and Macauley 1992). To ensure the quality of the milk during storage, the milk is stored at a temperature of $4-7^{\circ} \mathrm{C}$ (Chandler et al. 1990), and the average shelf life of stored milk is approximately 7 days (Khusniati et al. 2006). However, Heo (1989) examined commercial milk samples stored at $7.2^{\circ} \mathrm{C}$ and found that after 10 days of storage $91 \%$ of the milk was acceptable, whereas after 14 days, $82 \%$ of the whole milk was still acceptable.

The qualities of pasteurised milk in refrigerated storage were affected by the growth of psychrotrophic bacteria, especially Pseudomonas spp., and to keep the quality

$\overline{\text { *Corresponding author : tatikkhusni@yahoo.com }}$ 
of the milk at storage, the milk were stored at temperature of $4-7^{\circ} \mathrm{C}$ (Chandler $e t$ al. 1990). The psychrotrophic bacteria began to grow at the expiry date, and times after the expiry date. The bacteria, especially Pseudomonas spp grew rapidly in the stored milk. Furthermore, the different qualities of milk may have resulted from the different types of milk in storage. The quality of whole milk was higher than that of skim in the refrigerated storage, due to the higher lipid content in whole milk than that in skim (Janzen et al. 1982).

The main problem with milk, after the pasteurisation process, was recontamination. During the pasteurisation process in factories, psychotrophic bacteria are killed by the process. However, after pasteurisation, particularly if hygiene within the processing factory is poor, these psychotrophic bacteria can re-contaminate milk (Craven and Macauley 1992). During storage after the expiry date, the psychotrophic bacteria in the milk grew rapidly, and the longer the time of storage, the higher the growth and enzyme activities of psychotrophic bacteria within the milk (Chandler et al. 1990; Deeth et al. 2002)

The spoilage of pasteurised milk may result in microbial and chemical changes in the milk (Reinheimer et al. 1993). The biochemical changes of the milk at spoilage may have resulted from the activities of extracellular enzymes, especially protease, which degrades protein (Deeth et al. 2002; Janzen et al. 1982); and lipase, which degrades lipid (Deeth et al. 2002; Bucky et al. 1986). The addition of antibacterial and aromatic supplements, to reduce the spoilage, can be added to the milk. It is widely known that there are a lot of commercial antibacterial and aromatic plant materials produced in Indonesia, such as: honey, cinnamon, citronella (sweet), ginger, radish, turmeric, galingale, zingiber (roots), wild ginger, nutmeg, cardamom, cumin, pepper (seeds), garlic, clove, javanoni, galangale (bubs); green tea, laurellike (dried leaves); bamboo leaf, banana leaf, guava leaf, avocado leaf, betel vine, celery, garlic leaf, aloe vera (fresh leaves). These twenty-seven plant materials contain antibacterial and aromatic compounds, which may inhibit the growth and enzymatic activities of the psychotrophic bacteria within the stored milk.

Honey contains"inhibine", hydrogen peroxide and flavonoid (Lusby et al.2005); cinnamon contains cinamic acid, cinnamon oil, ethanol, methylene chloride, eugenol and benzyl benzoate (Tabak et al. 1999). The root materials of ginger contains "gingerin", gingerols, $\alpha$-zingiberene, shorgaols and ginger oil (Kikuzaki. 2000); radish has some glucosinolates and hexenyl acetate (Tirranen et al. 2001); turmeric has turmeric oil (Lantz et al.2005); galingale contains aromatic galingale (Anon 1999). Nutmeg contains diphenylpropanoids and ethyl acetate (Sherry et al.1982); cardamon contains aromatic cardamom (Mummenhoff and Hurka 1991); and pepper, adipic acid, piperine and oleorecine (Chitwood et al. 2003). Garlic contains 'allicin', free phenolics, p-coumaric, ferulic, p-hydroxybenzoic, garlic oil and vanillic acid, and specific garlic aromatic (Tirranen et al.2001); and javanoni contains anthraquinon and aromatic javanoni (Anon 2001). 
Citronella contains citronella oil and kingisidic acid; zingiber contains zingiber oil, acyclic oxygenated and monoterpenes; wild ginger roots contain wild ginger oil; clove contains clove oil, isobiflorin,biflorin, eugenol, phenolic compound and ferulic acid; cumin contains glycosides of 2-C-methyl-D-erythritol and cumin oil ; and galangale contains galangale oil (cineol, $\alpha$-pinene, eugenol, camphor, methyl cinnamate and sesquiterpenes) (Deans and Ritchie 1987).

The dried leaves of green tea contains polyphenol, phenolic acid, catechins, caffeine, flavonoid, epicatechin and ascorbic acid (An et al. 2004); and laurellike that has aromatic laurellike (Anon 2005). The fresh leaves of bamboo contains cinnamic derivatives (Tachibana et al.1992); banana has starch phosphorylase, polycyclic aromatic hydrocarbon and non-volatile organic acid (Palmer and Wyman 1965); guava contains aromatic guava leaf (Settheeworrarit et al.2005); and avocado contains (R)-2-hydroxy4-oxohenicosan-1-yl acetat, aldehydes, ketones, alcohols, terpenoides, estragole and 2-hexenal (Carman and Duffield 1995). The fresh leaves of celery contain apiole, 3-butylphthalide, sedanenolide, monoterpene hydrocarbon, phthalates and limonene (MacLeod and Ames1989); garlic containing garlic leaf lectin (Tirranen et al. 2001); aloe vera has glucomannans, uronic acid, glycoproteins, anthraquinon, saccharrides and phenolic compounds ( $\mathrm{Ni}$ et al. 2004); pandan contains pandan oil, monoterpene hydrocarbon and sesquiterpene hydrocarbon, while betel vine contains betel vine oil, eugenol, 1, 3 benzodioxol (5)-2-propenyl and anethole (Deans and Ritchie 1987).

The differences in the structure of the antibacterial compounds may have caused variation in the effectiveness of antibacterial substances and the aromatic materials in inhibiting spoilage bacteria and/or pathogenic bacteria. In the Indonesian dairy market, the supplements of strawberry and chocolate were added into the commercially pasteurised milk, and stored at refrigerated temperatures in cartons or plastic packages. The addition of these supplements was mainly to create more tastes and flavours for the consumers. These milk are produced in factories, located mainly in Java, and distributed not only to local areas but also outside Java. The shelf life of these milk is known to be around 7 days as is the shelf life of fresh milk. This may be due to the lack of antibacterial compounds within the supplements.

To make longer the shelf life of the commercial milk distributed both in the local area and outside the factories locations, antibacterial and aromatic materials may be used. It is expected that these materials, when added to milk in storage can suppress the growth and enzymatic activities of psychotrophic bacteria, thus increasing the quality and shelf life (the time started after completion of the pasteurisation process up to the time of expiry date), of pasteurised milk. This paper reports on the preservation of milk with the addition of antibacterial and aromatic supplements produced in Indonesia. 


\section{MATERIALS AND METHODS}

\section{Milk samples}

The same types, of commercially batched pasteurised milk, at a temperature of $85^{\circ} \mathrm{C}$ for 30 minutes, in 1 and 2 Litre cartons were used. The milk samples, stored at $4^{\circ} \mathrm{C}$ until use, were transported on ice to the laboratory, and a $100-\mathrm{mL}$ aliquot of each sample was then transferred aseptically into $200-\mathrm{mL}$ sterile bottles.

\section{Preparation of antibacterial and aromatic materials}

The collection of the 27 supplements from supermarkets and traditional markets was carried out in the Bogor area, Indonesia. All the materials selected were clean and in good condition

\section{Juice supplements extracted from antibacterial and aromatic materials}

Juice supplements were made by the extraction of juices from the antibacterial and aromatic materials. Fifty (50)-grams of the materials were then made into juice by the addition of $500 \mathrm{~mL}$ of boiled water. The materials were then homogenized by using a blender. The juices produced were subsequently filtered through a sterilized stainless steel filter with $\varnothing$ (diameter) $0.5 \mathrm{~mL}$, and the cleared juices were kept at a refrigerated temperature until ready for use as supplements.

\section{Pasteurised milk with the addition of supplements}

One and two Litre cartons of commercially pasteurised milk were used. The addition of extract after pasteurisation instead of before was because of: (1) The total bacterial counts after pasteurisation were lower than that of before. (2) The pathogenic bacteria were killed after pasteurisation, but the bacteria weren't killed before pasteurisation (3) Materials extracted were used for inhibiting psychotrophic bacteria, which caused the spoilage of the milk at storage. The milk was then transferred aseptically from the big bottles into $200 \mathrm{~mL}$ sterile bottles. One representative of each of the twenty-seven different liquid supplements was segregated into separate 200-mL aliquots of the batch of pasteurised milk. The samples, with the addition of the supplements, together with milk without supplements (controls), were incubated at $4^{\circ} \mathrm{C}$ for up to 5 days after the expiry date. At 5 days before the expiry date, samples of controls and the supplemented twenty-seven milk samples were organoleptically assessed. At 5 days after the expiry date, all the milk samples were investigated for total aerobic counts, acidities, and used for production of supernatants to be assayed for protease and lipase activities. The results presented for bacterial counts, protease activities, lipase activities and acidities are mean values for the three replicates. 
BIOTROPIA VOL.15 NO. 1, 2008

\section{Sensory assessments}

The sensory evaluation was conducted by 18 panellists, and assessed by a modified ranking test. The ranking test was as follows; the tastes, colours, flavours and homogeneity, of the milk' samples, were organoleptically evaluated with scores of: 1.00$<2.00$ (unacceptable), 2.00-<2.50 (less acceptable), 2.50-<2.65 (acceptable), and >2.65 (more acceptable). The characteristics of organoleptic assessments were tastes (acidic, sweet, plain, milky or others), colours (white, green, red or others), flavours (plain, acidic, sweet, milky or others), and homogeneity (homogeneous, non-homogeneous or others). The equation between the scores and the acceptability ranking was based on the results of the scores and the comments of the sensory evaluation of the milk samples.

\section{Total aerobic bacterial counts}

Ten-fold serial dilutions of the milk samples were made and spread plate counts performed according to Australian Standard AS 1766.1.4 using Nutrient Agar. The plates were incubated for $2-3$ days at $30^{\circ} \mathrm{C}$.

\section{Acidity measurement}

The acidities of the milk' samples were measured by base-acid titration. 10 $\mathrm{mL}$ of each milk sample was poured into Erlenmeyer $100 \mathrm{~mL}$ and several drops of phenolphthalein were added. The solutions were titrated by $\mathrm{NaOH} 0.1 \mathrm{~N}$ un-till the colours changed to pink. The formula of acidity (based on lactic acid) was A.B.90.1000/C [A: volume of $\mathrm{NaOH}$ used $(\mathrm{mL})$; $\mathrm{B}$ : concentration of $\mathrm{NaOH}$ standardized $(\mathrm{N})$; $\mathrm{C}$ : volume of milk titrated (mL); D: BE lactic acid (g/equivalent)].

\section{Preparation of the supernatants (crude enzymes)}

Bacterial cells were removed from the incubated milk samples (with and without the additional supplements) by centrifugation at $24000 \mathrm{~g}$ for $10 \mathrm{~min}$. at $4^{0} \mathrm{C}$. The resulting supernatants (crude enzymes) were collected and stored at $-20^{\circ} \mathrm{C}$ in sterile bottles until assayed for enzyme activities

\section{Protease assay}

Proteolytic activity was then assayed by the use of the azocasein method, using sulphanilamide-azocasein (Sigma Chemical Co., USA) as the substrate, according to the method of Christen \& Marshall (1984), with some modifications. The reaction mixture contained $2 \mathrm{~mL}$ of azocasein $(10 \mathrm{~g} / \mathrm{L}$, dissolved by heating $0.1 \mathrm{M}$-Tris- $\mathrm{HCl}$ buffer $\mathrm{pH} 7.4$ (sterile) containing $2 \mathrm{mM}-\mathrm{CaCl}_{2}$ at $63^{\circ} \mathrm{C}$ for 30 minutes) and $0.5 \mathrm{~mL}$ crude enzyme solution (supernatant) was incubated for $1 \mathrm{~h}$ at $37^{\circ} \mathrm{C}$. One unit of proteolytic activity was defined as the volume of enzyme solution $(\mathrm{mL})$ required for producing an absorbance increase at $345 \mathrm{~nm}$ of 0.01 A.U. in an hour under the assay conditions. 


\section{Lipase assay}

The lipase activity assay was carried out based on the assay procedure of a modified Dole extraction procedure (Deeth et al. 1975). The supernatants (crude enzyme; 0.5 $\mathrm{mL}$ ) , $0.25 \mathrm{ml}$ buffer (2 M-diethanolamine-HCL, $\mathrm{pH}$ 8.5), $3 \mathrm{ml}$ UHT cream, and 1 $\mathrm{mL}$ sterile water (in a stoppered test tube) were incubated at $40^{\circ} \mathrm{C}$ for 2 hours in a shaking (100-rpm) water-bath, and lipase activities were then measured by titration. The reaction mixture was added with $10 \mathrm{~mL}$ of extraction mixture (isopropanol: petroleum ether: $\left.4 \mathrm{~N} \mathrm{H}_{2} \mathrm{SO}_{4}\right)(40: 10: 1), 6 \mathrm{~mL}$ of petroleum ether, and $4 \mathrm{~mL}$ of water. The mixture was then shaken for $15 \mathrm{sec}$, and an-aliquot $(8 \mathrm{~mL})$ of the upper layer was transferred to a $50 \mathrm{~mL}$ conical flask and $0.5 \mathrm{~mL}$ of $0.02 \%$ bromothymol blue indicator was added. The free fatty acid (F.F.A) was titrated with $0.02 \mathrm{~N}$ methanolic $\mathrm{KOH}$. The activities of the supernatants are expressed as $\mu$ equiv. $\mathrm{mL}^{-1} \mathrm{~h}^{-1} \mathrm{using}$ the formulae:

$$
\frac{\mathrm{N}\left(\mathrm{T}_{\text {test }} / \mathrm{P}_{\text {test }}-\mathrm{T}_{\text {control }} / \mathrm{P}_{\text {control }}\right) \times 10^{3}}{\mathrm{~V} \times \mathrm{H}}
$$

Where $\mathrm{N}$ is the normality of the methanolic $\mathrm{KOH}, \mathrm{T}_{\text {test }}$ and $\mathrm{T}_{\text {control }}$ are the titration volumes for the test and the control respectively, $\mathrm{P}_{\text {test }}$ and $\mathrm{P}_{\text {control }}$ are the proportions of the upper layers titrated, $\mathrm{V}$ is the volume of enzyme solution and $\mathrm{H}$ is the incubation time in hours.

\section{Statistical analysis}

All treatments of all milk samples, with and without the addition of supplements, were statistically analysed by ANOVA with Factorial Complete Randomised Design (Snedecor and Cochran 1989) using General Linear Model with three replications.

\section{RESULTS AND DISCUSSION}

The organoleptic performances of all supplemented milk were generally better than that of the controls (without supplements), although the panellists classed some of them as organoleptically un-acceptable. Of the 27 supplemented whole milk samples 20, 4 and 3 samples at 5 days before the expiry date were classed as acceptable, less acceptable and unacceptable by panellists, while of the 27 supplemented skim milk samples 14,8 and 5 samples were classed as acceptable, less acceptable and unacceptable by panellists at the same date, respectively (Table 1 ).

The 20 supplemented whole milk samples contained honey, cinnamon, citronella, ginger, turmeric, galingale, zingiber, wild ginger, nutmeg, pepper, clove, galangale, green tea, laurellike, bamboo leaf, banana leaf, guava leaf, avocado leaf, betel vine and aloe vera. 
The 4 supplemented whole milk samples contained cumin, garlic, celery and garlic leaf, while the rest i.e. 3 supplemented whole milk samples contained radish, cardamom and javanoni.

The 14 supplemented skim milk samples contained honey, cinnamon, citronella, ginger, galingale, pepper, galangale, green tea, bamboo leaf, banana leaf, guava leaf, avocado leaf, betel vine and aloe vera. The 8 supplemented skim milk samples contained turmeric, zingiber, wild ginger, nutmeg, garlic, clove, laurellike and celery, while the 5 supplemented skim milk samples contained radish, cardamom, cumin, javanoni and garlic leaf.

Therefore, the 20 supplemented whole milk samples and the 14 supplemented skim milk samples were classed as acceptable, based on organoleptic assessments. To further classify their quality and shelf life, these acceptable milk, were then counted for total bacteria and measured for enzymatic activities and acidities

The preservation of the whole milk (Table 2) and skim (Table 3) can be explained by the lower total bacterial counts, proteolysis and lipolysis, and the acidities percentages which were not significantly different, than those of controls. This is caused by the lower production of psychotrophic bacteria within these milk. The total bacterial counts, protease and lipase activities, of the 20 acceptable whole milk, and the 14 acceptable skim, were significantly lower than that of the controls (without supplements), at the time of storage 5 days after the expiry date $(\mathrm{P}<0.05)$.

Table 1. The organoleptic performances of skim and whole milk with the addition of antibacterial and aromatic supplements, at 5 days before the expiry date

\begin{tabular}{cccc}
\hline No. & $\begin{array}{c}\text { Antibacterial and aromatic } \\
\text { supplements }\end{array}$ & Whole milk & Skim milk \\
\hline 1 & Honey & $>$ acceptable & $>$ acceptable \\
2 & Cinnamon & $>$ acceptable & acceptable \\
3 & Citronella & $>$ acceptable & $>$ acceptable \\
4 & Ginger & $>$ acceptable & $>$ acceptable \\
5 & Radish & unacceptable & unacceptable \\
6 & Turmeric & $>$ acceptable & $<$ acceptable \\
7 & Galingale & $>$ acceptable & acceptable \\
8 & Zingiber & acceptable & $<$ acceptable \\
9 & Wild ginger & acceptable & $<$ acceptable \\
10 & Nutmeg & acceptable & $<$ acceptable \\
11 & Cardamon & unacceptable & unacceptable \\
12 & Cumin & $<$ acceptable & unacceptable \\
13 & Pepper & $>$ acceptable & acceptable \\
14 & Garlic & $<$ acceptable & $<$ acceptable \\
15 & Clove & acceptable & $<$ acceptable \\
\hline
\end{tabular}


Table 1. Continued

\begin{tabular}{cccc}
\hline No. & $\begin{array}{c}\text { Antibacterial and aromatic } \\
\text { supplements }\end{array}$ & Whole milk & Skim milk \\
\hline 16 & Javanoni & unacceptable & unacceptable \\
17 & Galangale & $>$ acceptable & acceptable \\
18 & Green tea & acceptable & acceptable \\
19 & Laurellike & $>$ acceptable & $<$ acceptable \\
20 & Bamboo leaf & $>$ acceptable & acceptable \\
21 & Banana leaf & $>$ acceptable & acceptable \\
22 & Guava leaf & $>$ acceptable & acceptable \\
23 & Avocado leaf & $>$ acceptable & acceptable \\
24 & Betel vine & acceptable & acceptable \\
25 & Celery & $<$ acceptable & $<$ acceptable \\
26 & Garlic leaf & $<$ acceptable & unacceptable \\
27 & Aloe vera & $>$ acceptable & $>$ acceptable \\
28 & Milk (control) & $>$ acceptable & $>$ acceptable \\
\hline
\end{tabular}

Notes:

$>$ acceptable $(>2.65)$; acceptable $(\geq 2.50)$; $<$ acceptable $(\geq 2.00)$; unacceptable $(<2.00)$

The total bacterial counts of the 27 supplemented milk at storage 5 days after the expiry date, were in the range of $6.0 \times 10^{2}-8.4 \times 10^{4} \mathrm{cfu} / \mathrm{mL}$ (whole milk) and $8 \times 10^{2}-9.4 \times 10^{5} \mathrm{cfu} / \mathrm{mL}$ (skim milk), while the total bacterial counts of milk without supplements (controls) were $8.5 \times 10^{5} \mathrm{cfu} / \mathrm{mL}$ (whole milk) and $9.7 \times 10^{6} \mathrm{cfu} / \mathrm{mL}$ (skim milk) at the same times, respectively (Table 2-3). The total bacterial counts of the twenty (20) acceptable whole milk, and the fourteen (14) acceptable skim, were in the range of $6.0 \times 10^{2}-8.5 \times 10^{3} \mathrm{cfu} / \mathrm{mL}$ and $8.0 \times 10^{2}-9.3 \times 10^{4} \mathrm{cfu} / \mathrm{mL}$, respectively. Therefore, the 20 whole milk and the 14 skim milk categorized as acceptable were based not only on organoleptic performances, but also on total bacterial counts.

The protease activities of the 27 supplemented milk were in the range of 0.20 $0.40 \mathrm{U} / \mathrm{mL}$ (whole milk) and $0.30-0.50 \mathrm{U} / \mathrm{mL}$ (skim milk), at storage 5 days after the expiry date, while that of without supplements (controls) were $0.50 \mathrm{U} / \mathrm{mL}$ (whole milk) and $0.60 \mathrm{U} / \mathrm{mL}$ (skim milk), at the same times, respectively (Table 2-3). The protease activities of the 20 acceptable whole milk, and the 14 acceptable skim milk, were in the range of $0.20-0.35 \mathrm{U} / \mathrm{mL}$ and $0.30-0.45 \mathrm{U} / \mathrm{mL}$, respectively. Furthermore, the protease activities of the 15 out of the 20 acceptable whole milk were lower than that of the other 5, while the protease activities of the 10 out of the 14 acceptable skim milk were lower than that of the other $4(\mathrm{P}<0.05)$.

The protease activities of these 15 acceptable whole milk (added with honey, cinnamon, citronella, ginger, turmeric, galingale, zingiber, wild ginger, nutmeg, pepper, clove, galangale, green tea, bamboo leaf and aloe vera) were in the range of $0.20-0.30 \mathrm{U} /$ $\mathrm{mL}$, at 5 days after the expiry date, while the protease activities of these 10 acceptable 
skim milk (added with honey, cinnamon, citronella, ginger, galingale, pepper, galangale, green tea, bamboo leaf and aloe vera) were $0.30-0.40 \mathrm{U} / \mathrm{mL}$.

Thus, the 15 whole milk and the 10-skim milk categorized as acceptable were based not only on organoleptic performances and total bacterial counts, but also on protease activities.

The lipase activities of the 27 supplemented skim and whole milk were significantly lower than those without supplements (controls), and the lipase activities in supplemented whole milk were significantly higher than that in skim, at the storage 5 days after the expiry date $(\mathrm{P}<0.05)$ (Tables 2-3). The lipase activities of the supplemented milk were in the range of $0.17-0.27 \mu$ equiv. $\mathrm{mL}^{-1} \mathrm{~h}^{-1}$ (whole milk) and $0.11-0.22 \mu$ equiv. $\mathrm{mL}^{-1} \mathrm{~h}^{-1}$ (skim milk), at storage 5 days after the expiry date, while the lipase activities of the milk without supplements (controls) was 0.29 requiv. $\mathrm{mL}^{-1} \mathrm{~h}^{-1}$ (whole milk) and $0.24 \mu$ equiv. $\mathrm{mL}^{-1} \mathrm{~h}^{-1}$ (skim milk), at the same times, respectively. The lipase activities of the 20 acceptable whole milk and the 14 acceptable skim were in the range of $0.17-$

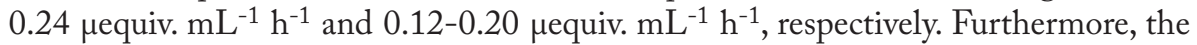
lipase activities of the 15 out of the 20 acceptable whole milk were lower than that of the other 5 , and that of the 10 out of the 14 acceptable skim were lower than that of the other four $(\mathrm{P}<0.05)$.

The lipase activities of the 15 acceptable whole milk (added with honey, cinnamon, citronella, ginger, turmeric, galingale, zingiber, wild ginger, nutmeg, pepper, clove, galangale, green tea, bamboo leaf and aloe vera) were $0.16-0.22 \mu$ equiv. $\mathrm{mL}^{-1} \mathrm{~h}-1$, at 5 days after the expiry date, while the 10 acceptable skim (additional honey, cinnamon, citronella, ginger, galingale, pepper, galangale, green tea, bamboo leaf and aloe vera) were 0.11-0.17 $\mu$ equiv. $\mathrm{mL}^{-1} \mathrm{~h}^{-1}$.

Thus, the 15 whole milk and the 10 skim classified as acceptable were based not only on organoleptic assessments, total bacterial counts and protease activities, but also on lipase activities.

The acidities of the 27 supplemented milk, at storage 5 days after the expiry date, were in the range of $0.27-0.36 \%$ (whole milk) and $0.29-0.39 \%$ (skim milk), while the acidities of milk without supplements (controls) were $0.26 \%$ (whole milk) and $0.28 \%$ (skim milk), at the same times, respectively (Tables 2-3). The acidities of the 20 acceptable whole milk and the 14 acceptable skim at 5 days after the expiry date were in the range of $0.27-0.34 \%$ and $0.29-0.37 \%$, respectively. Furthermore, the acidities of the 15 out of the 20 acceptable whole milk, and the 10 out of the 14 acceptable skim, at the same date, were in the range of $0.27-0.38 \%$ and $0.29-0.36 \%$, respectively. The acidities of the 15 acceptable whole milk, and the 10 acceptable skim milk, at 5 days after the expiry date, were not significantly different to that of the controls $(\mathrm{P}<0.05)$. 
The preservation of milk - T. Khusniati \& Y.Widyastuti

Table 2. Preservation of whole milk with the addition of antibacterial and aromatic supplements at 5 days after the expiry date

\begin{tabular}{|c|c|c|c|c|c|}
\hline No. & $\begin{array}{c}\text { Antibacterial and } \\
\text { Aromatic supple- } \\
\text { ments }\end{array}$ & $\begin{array}{l}\text { Total bacterial } \\
\text { counts }(\mathrm{cfu} / \mathrm{mL})\end{array}$ & $\begin{array}{l}\text { Protease activi- } \\
\text { ties }(\mathrm{U} / \mathrm{mL})\end{array}$ & $\begin{array}{l}\text { Lipase activities } \\
\text { ( } \mu \text { equiv. } \mathrm{mL}^{-1} \mathrm{~h}^{-1} \text { ) }\end{array}$ & Acidities (\%) \\
\hline 1 & Honey & $6 \times 10^{2}(\mathrm{k})$ & $0.20 \mathrm{i}$ & $0.17 \mathrm{klj}$ & $0.27 \mathrm{k}$ \\
\hline 2 & Cinnamon & $7 \times 10^{3}(f g)$ & $0.25 \mathrm{~h}$ & $0.18 \mathrm{ijk}$ & $0.28 \mathrm{jk}$ \\
\hline 3 & Citronella & $6.3 \times 10^{3}(\mathrm{gh})$ & $0.20 \mathrm{i}$ & $0.17 \mathrm{klj}$ & $0.30 \mathrm{hij}$ \\
\hline 4 & Ginger & $5 \times 10^{3}(\mathrm{i})$ & $0.20 \mathrm{i}$ & $0.17 \mathrm{klj}$ & $0.27 \mathrm{k}$ \\
\hline 5 & Radish & $8.3 \times 10^{4}(\mathrm{c})$ & $0.40 \mathrm{~d}$ & $0.26 b c$ & $0.35 \mathrm{cde}$ \\
\hline 6 & Turmeric & $7.2 \times 10^{3}(\mathrm{ef})$ & $0.20 \mathrm{i}$ & 0.19 hij & $0.29 \mathrm{ij}$ \\
\hline 7 & Galingale & $7.2 \times 10^{3}(\mathrm{ef})$ & $0.20 \mathrm{i}$ & $0.19 \mathrm{hij}$ & $0.29 \mathrm{ij}$ \\
\hline 8 & Zingiber & $8.4 \times 10^{3}(\mathrm{~d})$ & $0.30 \mathrm{~g}$ & $0.21 \mathrm{fgh}$ & $0.32 \mathrm{fgh}$ \\
\hline 9 & Wild ginger & $8.3 \times 10^{3}(\mathrm{~d})$ & $0.30 \mathrm{~g}$ & $0.20 \mathrm{ghi}$ & $0.32 \mathrm{fgh}$ \\
\hline 10 & Nutmeg & $8.3 \times 10^{3}(\mathrm{~d})$ & $0.30 \mathrm{~g}$ & 0.20 ghi & $0.32 \mathrm{fgh}$ \\
\hline 11 & Cardamon & $8.4 \times 10^{4}(\mathrm{c})$ & $0.40 \mathrm{~d}$ & $0.27 \mathrm{ab}$ & $0.36 \mathrm{bcd}$ \\
\hline 12 & Cumin & $8.3 \times 10^{4}(\mathrm{c})$ & $0.40 \mathrm{~d}$ & $0.26 \mathrm{bc}$ & $0.27 \mathrm{bcd}$ \\
\hline 13 & Pepper & $7 \times 10^{3}(\mathrm{f})$ & $0.25 \mathrm{~h}$ & $0.19 \mathrm{hij}$ & $0.28 \mathrm{jk}$ \\
\hline 14 & Garlic & $6 \times 10^{3}(\mathrm{~h})$ & $0.20 \mathrm{i}$ & 0.19 hij & $0.27 \mathrm{k}$ \\
\hline 15 & Clove & $8.3 \times 10^{3}(\mathrm{~d})$ & $0.30 \mathrm{~g}$ & 0.20 ghi & $0.32 \mathrm{fgh}$ \\
\hline 16 & Javanoni & $8.4 \times 10^{4}(\mathrm{c})$ & $0.40 \mathrm{~d}$ & $0.26 b c$ & $0.33 \mathrm{efg}$ \\
\hline 17 & Galangale & $8.3 \times 10^{3}(\mathrm{~d})$ & $0.30 \mathrm{~g}$ & $0.22 \mathrm{efg}$ & $0.28 \mathrm{jk}$ \\
\hline 18 & Green tea & $8.3 \times 10^{3}(\mathrm{~d})$ & $0.30 \mathrm{~g}$ & $0.21 \mathrm{fgh}$ & 0.31ghi \\
\hline 19 & Laurellike & $8.3 \times 10^{3}(\mathrm{~d})$ & $0.35 \mathrm{e}$ & $0.24 \mathrm{cde}$ & $0.33 \mathrm{efg}$ \\
\hline 20 & Bamboo leaf & $8.3 \times 10^{3}(\mathrm{~d})$ & $0.30 \mathrm{~g}$ & $0.21 \mathrm{fgh}$ & 0.31ghi \\
\hline 21 & Banana leaf & $8.4 \times 10^{3}(\mathrm{~d})$ & $0.35 \mathrm{e}$ & $0.24 \mathrm{cde}$ & $0.34 \mathrm{def}$ \\
\hline 22 & Guava leaf & $8.5 \times 10^{3}(\mathrm{~d})$ & $0.35 \mathrm{e}$ & $0.24 \mathrm{cde}$ & $0.34 \mathrm{def}$ \\
\hline 23 & Avocado leaf & $8.4 \times 10^{3}(\mathrm{~d})$ & $0.35 \mathrm{e}$ & 0.24 cde & $0.33 \mathrm{efg}$ \\
\hline 24 & Betel vine & $8.4 \times 10^{3}(\mathrm{~d})$ & $0.35 \mathrm{e}$ & $0.24 \mathrm{cde}$ & $0.33 \mathrm{efg}$ \\
\hline 25 & Celery & $8.4 \times 10^{4}(\mathrm{c})$ & $0.40 \mathrm{~d}$ & $0.25 \mathrm{bcd}$ & $0.35 \mathrm{cde}$ \\
\hline 26 & Garlic leaf & $8.3 \times 10^{3}(\mathrm{~d})$ & $0.30 \mathrm{~g}$ & $0.22 \mathrm{efg}$ & $0.32 \mathrm{fgh}$ \\
\hline 27 & Aloe vera & $6 \times 10^{3}(\mathrm{~h})$ & $0.20 \mathrm{i}$ & $0.16 \mathrm{klm}$ & $0.27 \mathrm{k}$ \\
\hline 28 & $\begin{array}{l}\text { Whole milk } \\
\text { (control) }\end{array}$ & $8.5 \times 10^{5}(b)$ & $0.50 \mathrm{~b}$ & $0.29 a$ & $0.26 \mathrm{k}$ \\
\hline
\end{tabular}

Note:

Numbers followed by different letters were significantly different $(\mathrm{P}<0.05)$ 
BIOTROPIA VOL. 15 NO. 1, 2008

Table 3. Preservation of skim milk with the addition of antibacterial and aromatic supplements at 5 days after the expiry date

\begin{tabular}{|c|c|c|c|c|c|}
\hline No. & $\begin{array}{l}\text { Antibacterial and } \\
\text { aromatic supple- } \\
\text { ments }\end{array}$ & $\begin{array}{c}\text { Total bacterial } \\
\text { counts (cfu/ } \\
\mathrm{mL})\end{array}$ & $\begin{array}{l}\text { Protease } \\
\text { activities } \\
(\mathrm{U} / \mathrm{mL})\end{array}$ & $\begin{array}{l}\text { Lipase activities } \\
\text { ( } \mu \text { equiv. } \mathrm{mL}^{-1} \mathrm{~h}^{-1} \text { ) }\end{array}$ & Acidities (\%) \\
\hline 1 & Honey & $8 \times 10^{2}(\mathrm{j})$ & $0.30 \mathrm{~g}$ & $0.12 \mathrm{op}$ & 0.30hij \\
\hline 2 & Cinnamon & $8 \times 10^{3}(\mathrm{de})$ & $0.35 \mathrm{e}$ & 0.13 nop & $0.31 \mathrm{ghi}$ \\
\hline 3 & Citronella & $7.2 \times 10^{3}(\mathrm{ef})$ & $0.30 \mathrm{~g}$ & 0.12 op & $0.33 \mathrm{efg}$ \\
\hline 4 & Ginger & $6 \times 10^{3}(\mathrm{~h})$ & $0.30 \mathrm{~g}$ & 0.12 op & $0.29 \mathrm{jk}$ \\
\hline 5 & Radish & $9.4 \times 10^{5}(\mathrm{ab})$ & $0.50 \mathrm{~b}$ & $0.21 \mathrm{fgh}$ & $0.38 \mathrm{ab}$ \\
\hline 6 & Turmeric & $8.1 \times 10^{3}(\mathrm{c})$ & $0.40 \mathrm{~d}$ & $0.15 \mathrm{lmn}$ & $0.34 \mathrm{def}$ \\
\hline 7 & Galingale & $8 \times 10^{3}(\mathrm{~d})$ & $0.30 \mathrm{~g}$ & $0.14 \mathrm{mno}$ & $0.32 \mathrm{fgh}$ \\
\hline 8 & Zingiber & $8.6 \times 10^{4}(\mathrm{~d})$ & $0.40 \mathrm{~d}$ & $0.16 \mathrm{klm}$ & $0.36 \mathrm{bcd}$ \\
\hline 9 & Wild ginger & $8.4 \times 10^{4}(\mathrm{c})$ & $0.40 \mathrm{~d}$ & $0.15 \mathrm{lmn}$ & $0.36 \mathrm{bcd}$ \\
\hline 10 & Nutmeg & $8.5 \times 10^{4}(\mathrm{c})$ & $0.40 \mathrm{~d}$ & $0.16 \mathrm{klm}$ & $0.36 \mathrm{bcd}$ \\
\hline 11 & Cardamon & $9.4 \times 10^{5}(\mathrm{ab})$ & $0.50 \mathrm{~b}$ & $0.22 \mathrm{efg}$ & $0.39 \mathrm{a}$ \\
\hline 12 & Cumin & $9.3 \times 10^{5}(\mathrm{ab})$ & $0.50 \mathrm{~b}$ & $0.21 \mathrm{fgh}$ & $0.39 \mathrm{a}$ \\
\hline 13 & Pepper & $8 \times 10^{3}(\mathrm{~d})$ & $0.35 \mathrm{e}$ & $0.14 \mathrm{mno}$ & 0.31ghi \\
\hline 14 & Garlic & $7.1 \times 10^{3}(\mathrm{f})$ & $0.30 \mathrm{~g}$ & $0.14 \mathrm{mno}$ & $0.29 \mathrm{jk}$ \\
\hline 15 & Clove & $8.5 \times 10^{4}(\mathrm{c})$ & $0.40 \mathrm{~d}$ & $0.15 \mathrm{lmn}$ & $0.36 \mathrm{bcd}$ \\
\hline 16 & Javanoni & $8.6 \times 10^{5}(b)$ & $0.45 \mathrm{c}$ & $0.19 \mathrm{hij}$ & $0.37 \mathrm{abc}$ \\
\hline 17 & Galangale & $8.1 \times 10^{3}(c)$ & $0.40 \mathrm{~d}$ & $0.17 \mathrm{klj}$ & $0.31 \mathrm{ghi}$ \\
\hline 18 & Green tea & $8.4 \times 10^{4}(\mathrm{c})$ & $0.40 \mathrm{~d}$ & $0.16 \mathrm{klm}$ & $0.36 \mathrm{bcd}$ \\
\hline 19 & Laurellike & $8.7 \times 10^{4}(\mathrm{c})$ & $0.45 c$ & $0.19 \mathrm{hij}$ & $0.37 \mathrm{abc}$ \\
\hline 20 & Bamboo leaf & $8.4 \times 10^{4}(\mathrm{c})$ & $0.40 \mathrm{~d}$ & $0.17 \mathrm{klj}$ & $0.36 \mathrm{bcd}$ \\
\hline 21 & Banana leaf & $9.0 \times 10^{4}(\mathrm{c})$ & $0.45 \mathrm{c}$ & $0.18 \mathrm{ijk}$ & $0.37 a b c$ \\
\hline 22 & Guava leaf & $9.3 \times 10^{4}(\mathrm{c})$ & $0.45 \mathrm{c}$ & 0.19 hij & $0.37 a b c$ \\
\hline 23 & Avocado leaf & $8.9 \times 10^{4}(\mathrm{c})$ & $0.45 \mathrm{c}$ & 0.19 hij & $0.36 \mathrm{bcd}$ \\
\hline 24 & Betel vine & $9.2 \times 10^{4}(\mathrm{c})$ & $0.45 \mathrm{c}$ & 0.20 ghi & $0.36 \mathrm{bcd}$ \\
\hline 25 & Celery & $9.4 \times 10^{5}(\mathrm{ab})$ & $0.50 \mathrm{~b}$ & 0.20 ghi & $0.38 \mathrm{ab}$ \\
\hline 26 & Garlic leaf & $8.4 \times 10^{4}(\mathrm{c})$ & $0.40 \mathrm{~d}$ & $0.17 \mathrm{klj}$ & $0.36 \mathrm{bcd}$ \\
\hline 27 & Aloe vera & $7 \times 10^{3}(\mathrm{fg})$ & $0.30 \mathrm{~g}$ & $0.11 \mathrm{p}$ & $0.29 \mathrm{jk}$ \\
\hline 28 & Skim milk (control) & $9.7 \times 10^{6}(a)$ & $0.60 \mathrm{a}$ & $0.24 \mathrm{cde}$ & $0.28 \mathrm{k}$ \\
\hline
\end{tabular}

Note:

Numbers followed by different letters were significantly different $(\mathrm{P}<0.05)$ 
The differences in the acceptability of the 15 acceptable whole milk and the 10 acceptable skim, may be due to the antibacterial and aromatic compounds of these supplements which were more effective in inhibiting bacterial growth and enzymatic activities of psychrotrophic bacteria in whole milk than that in skim.

The better organoleptic performances of the 15 acceptable whole milk than that of skim, at 5 days before the expiry date (Table 1), may be due to the higher lipid contents of the acceptable whole milk than that of the skim which may result in the better organoleptic performances of acceptable whole milk than that of skim. It has been reported that at 5 days before the expiry date (the designated expiry date), the tastes, flavours, colours and homogeneity of pasteurised milk were fresh due to, at that time, psychotrophic bacteria of Pseudomonas spp. hadn't grown yet (Bishop and white 1986; Chandler et al. 1990; Craven and Macauley 1992). The lipid contents of the whole milk were higher than that of the skim and the shelf life of the whole milk was higher than that of the skim, as supported by Chandler et al. (1990) and Deeth et al. (2002).

At storage 5 days after the expiry date, the antibacterial and aromatic compounds in the 15 acceptable whole milk, and the 10 acceptable skim, can suppress the bacterial counts, protease and lipase activities of psychrotrophic bacteria in skim and whole milk (Table 2-3). The differences in the total bacterial counts, protease and lipase activities between these 15 acceptable whole milk and 10 acceptable skim may be due to the differences in the type of the antibacterial and aromatic compounds, and the nutritional and organic acid compounds, of these acceptable skim and whole milk. It is known that the various antibacterial and aromatic compounds, nutritional compounds and acidities, of aromatic supplements, may have resulted in the different bacterial counts, protease and lipase activities between the supplemented skim and whole milk, at 5 days after the expiry date.

After the expiry date, the longer the time of storage may result in the higher total bacterial counts in refrigerated, pasteurised milk (Bishop and white. 1986; Chandler et al.1990; Craven and Macauley 1992), and the longer the time of storage, the higher the growth of psychotrophic bacteria, especially Pseudomonas spp. in refrigerated milk (Bishop and White 1986; Chandler et al. 1990; Craven and Macauley 1992). Furthermore, the protease activities of refrigerated pasteurized milk increased at times of storage, and the longer the time of storage the higher the protease activities of refrigerated milk (Janzen et al. 1982), and the lipase activities in refrigerated milk increased at the time of storage, also the higher the times of the storage the higher the lipase activities of refrigerated milk (Bucky et al.1986). For the aromatic supplements, there are various examples, with different $\mathrm{pH}$, which may affect the acidities of the skim and whole milk.

The lower bacterial growth of the 15 acceptable whole milk, at storage 5 days after expiry date, than that of the skim may be due to the increased effectiveness of the 
antibacterial compounds, in the acceptable whole milk, in inhibiting psychrotrophic bacteria, than that of in the skim. The higher lipid contents of the supplemented whole milk than that of the skim may have resulted in the stronger protection of bacterial attack, in the whole milk than that in skim. Bacterial growth of whole milk, in refrigerated storage, was lower than that in the skim (Chandler et al., 1990).

The lower protease activities of the 15 acceptable whole milk at storage, than that of the skim (Tables 2-3), may be due to the effectiveness of the antibacterial compounds, in the acceptable whole milk, in inhibiting protease activities of the psychrotrophic bacteria, than that in the skim. The higher lipid contents of the supplemented whole milk, compared to the skim, may have resulted in the stronger inhibition of the protease activities of psychrotrophic bacteria, on the supplemented whole milk than that on the skim. The protease activities of psychrotrophic bacteria in the whole milk at refrigerated storage were lower than that of the skim (Deeth et al.2002; Janzen et al. 1982). On the contrary, the higher lipase activities of the 15 acceptable whole milk in storage than that of the skim may be due to the higher lipid contents of the supplemented whole milk than that of the skim. The lipase activities in the whole milk, at refrigerated storage, were higher than that in the skim (Deeth et al.2002; Bucky et al.1986). The differences in the acidities between the 15 acceptable whole milk and the 10 acceptable skim in the storage, may be due to the differences in the organic acidic compounds between these acceptable skim and whole milk.

\section{CONCLUSIONS}

The study on the preservation of milk with an additional $10 \%$ of antibacterial and aromatic supplements, produced in Indonesia showed that 15 out of the 27 supplemented whole milk, and 10 out of the 27 skim (preserved milk) were tested and classified as acceptable. This classification was based on their better organoleptic performances, their lower bacterial counts, protease and lipase activities, and their acidities percentages which were not significantly different, compared to that of milk without supplements (unpreserved milk), at 5 days after the expiry date $(\mathrm{P}<0.05)$. These 15 acceptable whole milk contained honey, cinnamon, citronella, ginger, turmeric, galingale, zingiber, wild ginger, nutmeg, pepper, clove, galangale, green tea, bamboo leaf and aloe vera, and the 10 acceptable skim milk contained honey, cinnamon, citronella, ginger, galingale, pepper, galangale, green tea, bamboo leaf and aloe vera.

\section{ACKNOWLEDGEMENT}

The authors would like to acknowledge (1) JSPS-RONPAKU for providing the scholarship and (2) Biodiversity Projects of Research Centre for Biology, Indonesian Institute for Sciences for partly providing the funds for this research. 


\section{REFERENCES}

An, BJ., Kwak, JH., Son, JH., Park, JM., Lee,JY., Jo, C. \& M.W. Byun. 2004. Biological and antimicrobial activity of irradiated green tea polyphenols. Food Chem., 88, 549-555

Anonymous. 1999. Greater Galangale (Alpinia galangal [L.] Willd). Spice Pages: Greater $G a-$ langale (galangal, khaa, laos).

Anonymous. 2001. Javanoni, bad flavours which contain medicinal substances. Kompas (Newspaper). June. (In Indonesian).

Anonymous. 2005. AQUA Friend Tree. AQUA Water Information Center-AQUA Care.

Bishop,J.R. \& C.H.White. 1986. Assessment of dairy product quality and potential shelf life - a review. J. Food Protect., 49, 739-753

Bucky, A.R., Hayes, P.R. \& D.S. Robinson. 1986. Lipase production by a strain of Pseudomonas fluorescens in whole milk and skimmed milk. Food Microbiol., 3, 37-44

Carman, R.M. \& A.R. Duffield. 1995. The isolation of (R)-2-Hydroxy-4-oxohenicosan-1-yl acetate from avocado leaves. Tetrahedron Letters. 36, 2119-2120

Chandler, R.E., Ng, S.Y. \& R.R. Hull. 1990. Bacterial spoilage of specialty pasteurized milk products. CSIRO Food Res. Quarterly. 50, 11-14

Chitwood, R.L., Pangborn, R.M. \&W.Jennings. 2003. GCMS and sensory analysis of volatiles from three cultivars of capsicum. Food Chem., 11, 201-216

Christen \& Marshall. 1984. Selected properties lipase and protease of Pseudomonas fluorescens 27 produced in four media. J. Dairy Res., 67, 1680-1687

Craven,H.M. \& B.J. Macauley. 1992. Microorganism in pasteurized milks after refrigerated storage 3. Effect of milk processor. Australian Journal of Dairy Technology. 47, 50-55

Deans, S.G. \& G. Ritchie. 1987. Antibacterial properties of plant essential oils. Int. J. Food Microbiol., 5, 165-180

Deeth,H.C., Khusniati,T., Datta, N. \& R.B.Wallace.2002. Spoilage patterns of skim and whole milks. J. Dairy Res., 69, 227-241

Deeth, H.C., Fitz-Gerald, C.H. \& A.F.Wood. 1975. A convenient method for determining the extent of lipolysis in milk. Australian J. Dairy Technol., 30, 109-111

Heo, J.I. 1989. Statistical evaluation, sampling and testing for downstream psychotrophic contamination on shelf life of fluid milk products. Dissertation Abstracts International B-49, Abs. 4088

Janzen,J.J., Bishop,J.R. \& A.B. Bodine. 1982. Relationship of protease activity to shelf life of skim and whole milk. J. Dairy Sci., 65, 2237-2240

Khusniati, T., Purwiyanti, H., Widyastuti, N. \& Z.A. Mas' ud. 2006. The effect of green tea and ginger on homogenizes, acidities and protease activities of skim and whole milks. Int. Agric. Sci. J. GAKURIYOKU. 12, 22-26

Kikuzaki, H. 2000. Ginger for drugs and spice purposes. In Herbs, Botanicals and Teas. In Editor Mazza G and Oomah. Lancester. Technomic. 
BIOTROPIA VOL. 15 NO. 1, 2008

Lantz, R.C., Chen, G.J., Solyom, A.M., Jolad, S.D. \& B.N. Timmermann. $\square 2005$. The effect of turmeric extracts on inflammatory mediator production. Phytomedic., 12, 445-452

Lusby, P.E., Coombes, A.L. \& J.M. Wilkinson. 2005. Bactericidal activity of different honeys against pathogenic bacteria. Archs Medical Res., 36, 464-467

MacLeod, G. \& J.M. Ames. 1989. Volatile components of celery and celeriac. Phytochem., 28, 18171824

Mummenhoff, K. \& H. Hurka. 1991. Isoelectric focusing analysis of RUBISCO in Lepidium (Brassicaceae), sections Lepia, Lepiocardamon and Cardamon. Biochem. Syst. and Ecol., 19, 47-52

Ni, Y., Turner, D., Yates, K.M. \& I. Tizard. 2004. Isolation and characterization of structural components of Aloe vera L. leaf pulp. Int. Immunopharmacol., 4, 1745-1755

Palmer, J.K. and A.H. Wyman. 1965. The organic acids in banana leaves. Phytochem., 4, 305-309

Reinheimer,J.A., Suarez, V.B. \& M.A. Haye. 1993. Microbial and chemical changes in refrigerated pasteurized milk in the Santa Fe area (Argentina). Australian J. Dairy Technol., 48, 5-9

Settheeworrarit, T., Hartwell, S.K., Lapanatnoppakhun, S.,Jakmunee,J., Christian, G.D. \& K. Grudpan. 2005. Exploiting guava leaf extract as an alternative natural reagent for flow injection determination of iron. Talanta. Elsevier. B.V. (In press)

Sherry, C.J., Ray, L.E. \& R.E. Herron. 1982. The pharmacological effects of a ligroin extract of nutmeg (Myristica fragrans). J. Ethnopharmacol., 6,61-66

Snedecor, G.W. \& W.G. Cochran. 1989. Statistical Methods, $8^{\text {th }}$ Edn. Iowa State University Press. Ames, Iowa

Tabak, M., Armon, R. \& I. Neeman. 1999. Cinnamon extracts`inhibitory effect on Helicobacter pylori. J. Ethnopharmacol., 67, 269-277

Tachibana, S., Ohkubo, K. \& G.H.N. Towers. 1992. Cinnamic acid derivatives in cell walls of bamboo and bamboo grass. Phytochem., 31, 3207-3209

Tirranen, L.S., Borodina, E.V., Ushakova, S.A., Rygalov, V.YE.. \& J.I. Gitelson. 2001. Effect of volatile metabolites of dill, radish and garlic on growth of bacteria. International Astronautical Federation. Elsevier Science Ltd. Britain. 49, 105-108 